\title{
STRUKTURA SUBSTANCJALNA OSOBY LUDZKIEJ
}

Człowiek jest złożeniem duszy i ciała, czyli substancji duchowej i materialnej. Wspólnie nie tworzą one jakiejś trzeciej substancji, lecz osobę. Nie istnieje substancja, która byłaby mieszanką duchowo-materialną. Jest to niemożliwe. Substancja może być albo duchowa, albo materialna. Materialiści uznają, że istnieje tylko substancja materialna, która jednak ma wszystkie atrybuty substancji duchowej. Materia myśli, czuje i ma wolę. Jeżeli do tego dodamy pogląd o wieczności materii, to okazuje się, że ma ona wszystkie atrybuty boskie. Teologia chrześcijańska uznaje istnienie dwóch substancji: duchowej i materialnej, przy czym materia jest tylko jedna (stworzona), natomiast substancje duchowe są trzech rodzajów: niestworzona, stworzona duchowa i stworzona materialna. Osoba ludzka złożona jest z dwóch substancji stworzonych: duchowej i materialnej. Substancja niestworzona jest trynitarna, tworzą ją trzy Osoby Boskie.

Struktura ciała ludzkiego jest taka sama jak całej materii, ale oprócz tego są w niej elementy wynikające ze zjednoczenia personalnego z duszą. Struktura duszy ma elementy wspólne z substancją boską i substancją anielską, ale ponadto jest w niej coś, co otwiera ją na materię. Dusza ludzka jest formą ciała, nawet wtedy, gdy egzystuje bez ciała. Właściwość ta nie jest okazjonalna, lecz należy do jej istoty. Każda osoba (substancja duchowa jednostkowa) ma w sobie coś, czego nie mają inne osoby. Tę specyficzną, nieprzekazywalną właściwość ma również ciało ludzkie, czyli ciało zjednoczone z duszą. Po śmierci ciało nie ma żadnych właściwości personalnych. Termin „ciało ludzkie” odnosi się tylko do ciała zjednoczonego z duszą. Jest ono wtedy tak samo personalne, jak dusza. Obie substancje ludzkie mają takie właściwości, jakie ma osoba ludzka. 


\section{Personalność substancji duchowej i cielesnej w czlowieku}

Osoba ludzka nie może być radykalnie osobna. $\mathrm{Z}$ jednej strony ma w sobie coś tylko swojego (osobność), a z drugiej - otwartość, wspólnotowość. Osoba ma coś niedającego się przekazać, a jednocześnie dąży do relacji z innymi. Z tego względu tworzenie jedności współbrzmi z zachowaniem autonomii. Wszystkie właściwości personalne są skondensowane, tworzą personalną esencję. Nie są to tylko abstrakcyjne cechy, mają charakter ontyczny tak gęsty, że stanowią personalną substancję. Natężenie substancjalne w osobie stworzonej jest względne, tak jak samo istnienie. W Osobie absolutnej gęstość budulca jest absolutna. Właściwości personalne są zagęszczone tak bardzo, że tworzą zwarty budulec, i odwrotnie, substancja jest utkana z właściwości personalnych.

W refleksji personalnej, dotyczącej substancji z jej wewnętrznym wyposażeniem, można stosować analogie zakorzenione w refleksji nad strukturą bytów materialnych. Dziś fizyka przyjmuje, że masa jest utworzona z czasu i przestrzeni, a tym samym dochodzi do wniosku, że substancja materialna (masa) nie istnieje. Wszystko jest mniej lub bardziej gęstą, uniwersalną mgłą. W kategorii bytów duchowych jest inaczej. Substancje duchowe są indywidualne, nie tworzą jednego bytu duchowego. Jest natomiast różnica między Absolutem a bytami stworzonymi, w których można mówić o względności natężenia esencjalnego, a nawet o jego zmienności. Jest jakaś fundamentalna gęstość substancji danego bytu stworzonego, proporcjonalna do stopnia jego istnienia, ale jest też możliwość zmiany w zależności od stopnia relacji ze Stwórcą.

Mówiąc o tym, teologia posługuje się metaforami czerpanymi z różnych nauk szczegółowych. Metafory należą zawsze do języka poezji, który nie ma metafizycznej precyzji, ale nie jest też czystą abstrakcją. Nie potrafi wypowiedzieć wszystkiego do końca, ale wypowiada prawdę o czymś, co jest niepoznawalne, ale istnieje, $i$ to o wiele mocniej niż świat materialny. ${ }^{1}$

1 Zob. J. M a r i t a i n, La poesía y el arte, tłum. L.A. B i x i o, Buenos Aires 1955, s. 143-144; por. M. K r u p a, Duch i litera, Liryczna ekspresja mistycznej drogi św. Jana od Krzyża w przekładach polskich Wrocław 2006 (mps), s. 46. 
Substancja osoby jest spójna, odrębna wobec innych substancji personalnych, ale jednocześnie jest otwarta i ze swej istoty dąży do wzajemnych relacji. Tak jest z Osobami Boskimi, aniołami i ludźmi, przy czym w odniesieniu do ludzi istnieje spójność każdej dwóch substancji z osobna: materialnej i duchowej, a także spójność ich personalnego złożenia. Zagadnienie gęstości substancji nakłada się na zagadnienie gęstości personalnej ich złożenia. Ucieczką od problemu jest redukcja substancji osoby ludzkiej tylko do materii albo tylko do substancji duchowej. Jest to ucieczka od chrześcijaństwa, bo tylko w Nowym Testamencie jest mowa o pełni integralności człowieka. W ramach antropologii jest to ucieczka do schematu Starego Testamentu albo do schematu filozofii greckiej. ${ }^{2}$ Musiało minąć wiele wieków, aby refleksja systematyczna mogła ogarnąć całą treść Nowego Testamentu, w całym zakresie i w jej najgłębszym sensie. Dziś jest to możliwe dzięki postępowi nauk biblijnych z jednej strony i nauk przyrodniczych z drugiej.

Najwyższy stopień jedności ciała z duszą jest w Chrystusie, który, będąc Osobą Boską, przyjął we wcieleniu ludzkie ciało, które sam ulepił. W jakiś sposób wcielenie rozpoczęło się wraz ze stworzeniem pierwszego człowieka. Syn Boży stworzył ciało i duszę pierwszego człowieka po to, aby później przyjąć ciało i duszę do swojej Osoby. Pełnia jedności personalnej natury ludzkiej Chrystusa osiągnięta została w zmartwychwstaniu. Chrystus jest drugim Adamem, ma w sobie pełnię człowieczeństwa, a tym samym jest źródłem stwarzającym i dającym pełnię personalną wszystkim osobom stworzonym. ${ }^{3}$ W tajemnicy Chrystusa kwestia spójności natury ludzkiej (od wcielenia do uwielbienia) łączy się z kwestią zjednoczenia z naturą boską. Antropologia połączona $\mathrm{z}$ chrystologią daje pełnię personalizmu. ${ }^{4}$

2 Por. J. L e a 1, Notas para un estudio semántico de la Concepción Tertulianea del hombre en el tratado sobre la resurreción de la carne, Augustianum 1/1998, s. 97.

S. F e r n á n d e z - A r d a n a z, Elementi di antropologia somatica nella letteratura Latina cristiana (dalle origini al sec. V), Antonianum 71/1996, s. 8-10.

4 S. R a p o n i, Il tema dell'immagine-somiglianza nell'antropologia dei padri, w: E. A n c i 11 i (red.), Temi di antropologia teologica, Roma 1981, s. 309. 
Schemat ogólny osoby ludzkiej jest bardzo prosty. Substancja osoby złożona jest z substancji duchowej i materialnej. Głębsza refleksja prowadzi do ukazania nie tylko struktury wewnętrznej ciała i duszy, ale całości ujmującej wnętrza dwóch substancji w ich złożeniu personalnym. $Z$ tego wynika, że rozwinięcie tematu artykułu wymaga najpierw wykazania personalności ciała ludzkiego. W jedności z duszą ciało „rozjaśnia się, zwieńcza, osiąga swoją pleromę i spełnia się w sposób absolutny. Nie można sobie wyobrazić ani pomyśleć bytu doskonalszego niż osobowy". "Stwierdzenie, że osoba jest bytem najdoskonalszym, jest prawdziwe, ale w istocie swej banalne. Dopiero wykazanie personalności ciała i ukazanie pełnej struktury osoby ludzkiej nadaje temu stwierdzeniu należytą treść i znaczenie. Byt wyłącznie materialny nie może być osobą, może mieć tylko niektóre aspekty osobowe, ale bez złączenia z duszą osobą być nie może.

Ponadto trzeba zauważyć, że istnieją tylko dwa rodzaje bytów: materialne i duchowe. Każdy byt duchowy (substancjalny) jest osobą. Jeżeli są tylko dwa rodzaje bytów: materialne i duchowe, czyli osoby i byty, które osobami nie są i być nie mogą, to znaczy, że są byty niedoskonałe i doskonałe. Jeżeli są tylko dwie możliwości, to nie mówi się, że jedna z nich jest najdoskonalsza, lecz tylko tyle, że jest doskonała, a druga nie jest doskonała. Stopień najwyższy występuje wtedy, gdy są do wyboru co najmniej trzy możliwości. Złożenie substancji duchowej z materialną w osobie ludzkiej nie wytwarza trzeciego rodzaju substancji. Nawet gdyby ktoś to złożenie uważał za trzeci rodzaj substancji, to wystarczy powiedzieć, że tego rodzaju byt jest doskonalszy od bytu czysto materialnego, a nie, że jest bytem najdoskonalszym. Ostatecznie nie trzeba wykazywać tego, że osoba jest bytem najdoskonalszym, lecz tylko to, że jest bytem doskonalszym od materii. Tego rodzaju zagadnienie sprowadza się do stwierdzenia, że substancja duchowa jest doskonalsza od substancji materialnej. Dopiero w tej sytuacji w pełni wyrazisty staje się szok spowodowany stwierdzeniem, że materia (ciało zjednoczone z duszą) ma cechy personalne, jest osobą. Najpierw trzeba wykazać, że

5 Cz. S. B a r t n i k, Personalizm, Lublin $2000^{2}$, s. 96. 
materia (bez duszy) nie jest osobą, a następnie, że materia (zjednoczona z duszą) jest osobą.

Tego rodzaju zabieg jest analogiczny do pedagogii objawienia Bożego. Najpierw Bóg - przez wieki - doprowadził do przekonania, że jest tylko jeden Bóg, a dopiero wtedy objawił, że są trzy Osoby Boże. Gdyby to zostało objawione wiele wieków wcześniej, byłoby przyjęte powszechnie, ale w błędnym sensie, jako dodanie trzech do wielkiej liczby bogów. W sytuacji wyraźnego monoteizmu mówienie o trzech Osobach Boskich było szokiem, zgrzytem, paradoksem. Teologia polega na wyjaśnieniu tego, co oznacza jeden Bóg w trzech Osobach. Analogicznie do tego, antropologia dopiero po wykazaniu tego, że materia nie może być osobą wyjaśnia, co to znaczy, że ciało ludzkie jest osobą. Osobą jest tylko materia subsystująca w duszy ludzkiej. Ciało jest bytem subsystentnym, czyli wszczepionym w główne podłoże, którym jest dusza i uczestniczącym w jego działaniach personalnych.

Inny jest sens subsystowania duszy i ciała w sobie, inny jest sens subsystowania osoby ludzkiej w substancji duchowej i materialnej. W pierwszym ujęciu wyjaśniany jest sposób przebywania ciała w osobie, a dokładniej - w duszy ludzkiej. W drugim ujęciu wyjaśniane jest to, że wszystkie aspekty personalne są zarówno w duszy, jak też i w ciele ludzkim, że w jakiś sposób elementy personalne tkwią w substancji materialnej, a nie tylko w substancji duchowej. Z tym zagadnieniem wiążą się pytania dotyczące jaźni, pamięci, intelektu, uczuć i woli. Wszystko to dotyczy nie tylko duszy, ale i - zjednoczonego z duszą - ciała. Można mówić o jaźni zwierzęcej. Zwierzę ma jakieś aspekty personalne, ale osobą nie jest, nie ma substancji duchowej, nie jest substancją duchową. Czym innym jest jaźń w bycie materialnym pozbawionym duszy, a czym innym jaźń w ciele ludzkim zjednoczonym z duszą. Są czynione porównania jaźni zwierzęcej z ludzką. Niewiele jest refleksji dotyczących jaźni w substancji materialnej ludzkiej. ${ }^{6}$

$6 \quad$ Por. tamże, s. 59. 
Nie ma jaźni w martwym ciele człowieka po śmierci. Martwe ciało nie ma cech personalnych. Według Starego Testamentu, człowiek to materia ożywiona przez Boga. Dla staroży tnych Greków człowiek to materia ożywiona przez moc znajdującą się we wszechświecie. W obu przypadkach człowiek nie jest osobą, bo nie ma substancji duchowej, niezależnej od materii. Arystoteles pod nazwą „,dusza” rozumiał tylko formę, która sama nie jest substancją, nie jest budulcem duchowym. Według niego, jedyny rodzaj budulca to masa materialna. Osoba, czyli forma (jaźń) subsystuje tylko w materii. ${ }^{7}$ Mówiąc „forma substancjalna" starożytny filozof myślał tylko o bytowaniu formy (czystego schematu) w substancji materialnej. Zdecydowanie czym innym jest metafizyczne złożenie materii pierwszej z formą substancjalną (w postaci jednostkowego istnienia materii), a czym innym złożenie dwóch różnych obiektów, z których każdy - metafizycznie - złożony jest z jakiejś swojej materii pierwszej i swojej formy substancjalnej. Arystoteles nie uznawał istnienia indywidualnej substancji duchowej. Byt realny - dla niego - to tylko byt materialny. Uważał on m. in., że gwiazdy są bytami żywymi, ale - jak wszystko - są tylko materialne. Piąta esencja - quinta essentia - eter, to tylko sposób istnienia (oprócz czterech żywiołów) tej samej wszech-materii. Dusza u Arystotelesa to czysta forma tkwiąca w materii, całkowicie po stronie materii. Odrębny od niej w człowieku jest jedynie intelekt, który nie należy do człowieka, jest tożsamy z ,intelektem czynnym” uniwersalnym, $\mathrm{z}$ kosmosem, nie jest elementem ludzkim. ${ }^{8}$ Po śmierci wraca do kosmosu, podobnie do tego, jak starotestamentalny „duch ludzki” nie jest integralnym elementem człowieka i po śmierci wraca do Boga. Człowiek znika albo trwa w postaci cienia (cień ciała i cień duszy). Dopiero Nowy Testament wprowadził radykalną nowość: substancje duchową człowieka, i to nie tylko jako dodatek do ciała, lecz wręcz odwrotnie, jako fundamentalny element osoby ludzkiej. Niestety, antropologia Nowego Testamentu nie stała się tematem refleksji teologicznych, aż do dziś.

7 Por. M. A. K r ą p i e c, Ja-człowiek, Lublin 1991, s. 134.

8 Por. tamie, s. 135. 
Bartnik zauważył, że „nauka Nowego Testamentu o duszy nie została jeszcze opracowana dogłębnie. Kościołowi wystarczała tradycja filozoficzna, ułożona obok antropologii Starego Testamentu. Tymczasem Nowy Testament wychodzi zarówno poza antropologię filozoficzną, jak również poza antropologię biblijną. Trzeba nadrobić zaległości, co dziś jest możliwe, w sytuacji rozwoju nauk biblijnych i filozoficznej hermeneutyki personalistycznej". ${ }^{9}$ Zadziwia i niepokoi fakt, że myśliciele chrześcijańscy, zamiast mówić o ludzkiej substancji duchowej, której istnienie jest wnioskiem $\mathrm{z}$ wydarzenia zmartwychwstania Jezusa Chrystusa, ciągle trwają w nurcie filozofii greckiej i mówią tylko o bez-substancjalnej formie ciała ludzkiego, albo ograniczają się do myśli starotestamentalnej. Tylko niektórzy teologowie uznają, że człowiek to dwie substancje: cielesna, ale przede wszystkim duchowa. Niestety, oni też są przekonani, że informacja ta zaczerpnięta jest od starożytnych filozofów, a jest to przekonanie błędne. Inni obstają przy jednej substancji - materialnej, tak jak myśliciele starotestamentalni oraz wszyscy myśliciele pogańscy. Trwa dziwne przekonanie, że tylko to jest antropologia biblijna, że antropologia Nowego Testamentu nie jest biblijna. Takie przekonania przyczyniają się do rozwoju przechodzenia sposobu myślenia od chrześcijańskiego do pogańskiego. Trzeba się temu przeciwstawić, trzeba odczytywać i przedstawiać pełnię objawionej prawdy chrześcijańskiej. Słuszne jest korygowanie błędów w wierze, ale konieczne jest też uzupełnianie przemilczeń, niwelowaniem „,białych plam”.

Trzeba zwracać uwagę na argumenty, ale fundamentalną przyczyną wypaczeń prawdy jest sposób myślenia. Chrześcijaństwo to nie tylko zbiór prawd: starych i nowych, ale też nowy sposób myślenia: integralny, personalny, w pełni prawdziwy. W tym kontekście trzeba odpowiednio odczytywać sens wypowiedzi św. Tomasza, gdy pisał w swym komentarzu do Sentencji: „Ciało i dusza nie są dwoma substancjami istniejącymi i realizującymi się, ale z ich związku wynika jedna substancja w całości” (II, 69). Na ten tekst powołuje się wielu

9 Cz. S. B a r t n i k, Dogmatyka katolicka, t. 1, Lublin 2000, s. 383. 
filozofów i teologów. ${ }^{10}$ Tymczasem trzeba się zastanowić nad tym, jaką treść nadawał św. Tomasz określeniu ,jedna substancja”? Czy myślał w tym konkretnym wyrażeniu o jednym budulcu, czy myśli raczej tylko o jednym podłożu dla wszystkich elementów personalnych, dążąc do wykazania, że ciało zjednoczone z duszą też ma wszystkie właściwości personalne. Odpowiedź tkwi w bezpośrednim kontekście oraz w całości jego poglądów. Tomasz wyraźnie uznawał istnienie dwóch substancji: duchowej i materialnej, a duszę uważał za substancję, która jest formą ciała. Nie wystarcza rozwiązywanie poszczególnych kwestii za pomocą odpowiednich argumentów. Trzeba budować antropologiczny model, ujęcie całościowe, spójne, integralne. Stawką nie jest przyznanie komuś racji, lecz możliwość wyjścia poza schemat dyskursu i budowania modelu integralnego. Zasadniczym zadaniem teologii jest opisywanie całościowej struktury, ukazywanie sieci relacji, wyjaśnianie sposobu łączenia poszczególnych elementów ze sobą, łączenia ich z całością i pełne wyjaśnianie, na czym polega owa całość.

Czwarty Sobór Laterański odrzucił poglądy dualistyczne, czyli rozdzielające, sprowadzające refleksje tylko do duszy albo tylko do ciała. Sobór w Vienne stwierdził, że łączą się one substancjalnie. Nie oznacza to jednak utworzenia jednej substancji, lecz to, że więź między duszą i ciałem jest bardzo mocna, że nie łączy ich coś przypadłościowego. Spoiwem jest substancja duchowa, będąca formą ciała, która je personalizuje. Ważna przy tym jest kwestia metodologiczna, wybitnie chrześcijańska. Oparciem sformułowań antropologicznych Soboru w Vienne jest dogmat sformułowany na Soborze w Chalcedonie. W tym świetle trzeba tworzyć antropologię chrześcijańską, wyprowadzoną ze słów i wydarzeń Jezusa Chrystusa. Prawdą jest, że do wyjaśnienia tajemnicy Chrystusa trzeba rozumienia znaczenia natury ludzkiej i natury boskiej, ale prawdą jest też, że w celu zrozumienia natury ludzkiej trzeba wyjść od tajemnicy Chrystusa. Nie można zrozumieć personalności ciała ludzkiego bez

10 Zob. G. R a v a s i, Krótka historia duszy, tłum. A. W o j n o w s k i, Kraków 2008, s. 190. 
zastanowienia się nad misterium wcielenia. Filozofia i antropologia starotestamentalna są tylko punktem odniesienia. Nie mogą niczego narzucać. Zasadniczym źródłem, punktem wyjścia, są czyny i słowa Jezusa Chrystusa. Tego rodzaju antropologię chrystologiczną próbowali rozwijać ojcowie Kościoła. Była to tylko próba, i tak później zapomniana. ${ }^{11}$ Dziś nie wystarczy przypominanie. Trzeba kontynuować wielkie dzieło odczytywania i wyjaśniania prawdy objawionej, aż do integralnej pełni, jak to tylko jest możliwe.

\section{Powiązanie wyposażenia personalnego $z$ indywidualną substancją duchową}

Indywidualne substancje duchowe zostały stworzone na obraz Boży w celu osiągnięcia pełni podobieństwa Bożego. Według Maksyma Wyznawcy, Bóg dał substancji racjonalnej boskie właściwości, $\mathrm{z}$ których najważniejsza to trwanie $\mathrm{w}$ istnieniu na zawsze. $\mathrm{Z}$ kolei najważniejszymi właściwościami personalnymi są dobroć i mądrość, które są związane z wolą ludzką. Dzięki nim człowiek w swojej substancji duchowej i materialnej może osiągnąć uczestnictwo w życiu Boga. Z obrazem Bożym wiąże się niezniszczalność substancji duchowej człowieka, natomiast dobroć i mądrość (świętość) decydują o podobieństwie człowieka do Boga. ${ }^{12}$

Maksym Wyznawca, tak samo jak Anicius Manilus Boethius, odnosił termin substantia nie tylko do materii, jak czynili to mędrcy helleńscy a później myśliciele hellenistyczni, lecz również do duchowego budulca człowieka. ${ }^{13}$ Myśliciele starożytni zastanawiali się nad tym, co różni człowieka od zwierzęcia. Arystoteles wskazywał na wyposażenie wewnętrzne indywidualnego bytu wyodrębnionego z przyrody. Wszystkie tego rodzaju dyskusje prowadzone były w ra-

1 Por. J. L. R u i z de 1 a P e ñ a, Imagen de Dios. Antropología teológica fundamental, Sal Terrae, Colección "Presencia teológica" 49, Santander 1988², s. 111.

12 Por. P. A r gá r a t e, El hombre creado a la imagen y semajanza de Dios en San Máximo el Confesor, Communio 30 (1997) f. 2-3, s. 215.

13 Por. Cz. S. B a r t n i k, Personalizm, s. 38. 
mach założenia, że istnieje tylko jeden rodzaj substancji, że nie ma nic poza materią. Nawet objawienie Pierwszego Przymierza umieszczało pierwiastek życia dany przez Boga tylko w materialnym ciele ludzkim. Nie ma tam mowy o substancji duchowej w człowieku. Człowiek to ciało ożywione duchem danym od Boga. ${ }^{14}$ Podobnie określają człowieka materialiści, którzy uważają, że materia w swej całości jest bytem żywym, myślącym, posiadającym wolę i uczucia. Różnica polega na tym, że ciało otrzymuje swe życie nie od Boga Stworzyciela, lecz od wszech-materii. Człowiek to jednostkowe skondensowanie personalnych cech wszech-materii. Śmierć polega na tym, że życie zawarte w danej cząstce wszech-materii przechodzi do innej jej części. W naszych rozważaniach ważne jest to, że antropologia filozofów greckich i antropologia biblijna Starego Testamentu mówiły tylko o jednej substancji w człowieku. Dopiero Nowy Testament wprowadził myśl o substancji duchowej, która jest innego rodzaju budulcem niż masa (substancja) materialna. Tym samym dopiero w Nowym Testamencie pojawia się substancja duchowa, która nie jest częścią jakiejś substancji uniwersalnej, lecz jest faktycznie indywidualna. Dopiero wtedy pojawia się myśl o istnieniu osoby, czyli substancji rozumnej indywidualnej. ${ }^{15}$ Nie wystarczy powiedzieć, że człowiek jest żywą istotą rozumną. Trzeba powiedzieć, że rozumność jest wyposażeniem substancji duchowej, indywidualnej. ${ }^{16}$

14 Warto zastanowić się nad tym, kto i kiedy zaczął mówić o ludzkiej substancji duchowej. W każdym razie Boecjusz używał tego terminu w refleksji filozoficznej, natomiast Maksym Wyznawca w refleksji teologicznej. Warto też zastanowić się nad tym, kiedy w nauczaniu Kościoła pojawiła się myśl o możliwości istnienia substancji duchowej człowieka bez ciała, a także nad tym, kto i kiedy zaczął mówić, że jest to absolutnie niemożliwe. Jest to wielki temat wymagający odrębnych badań.

15 Por. Cz. S. B a r t n i k, Ku definicji osoby, Teologia w Polsce 1 (2007) nr 1, s. 6 .

16 Por. tamże, s. 8. Termin „istota” został użyty jako synonim terminu „byt”, Tymczasem oznacza on schemat, strukturę a nie jest synonimem terminu „byt”. Byt to istnienie oraz istota (forma). Człowiek nie jest formą, lecz bytem, który ma swoją formę (istotę). 
Najważniejszym elementem istoty, czyli wyposażenia wewnętrznego człowieka, jest rozumność. Może ona mieć różny kształt, mogą istnieć różne sposoby myślenia, rozumność może być wieloraka. Zawsze jednak stanowi wyposażenie ludzkiej substancji duchowej. Dla przykładu, myśliciel rosyjskiej, I. W. Kirejewskij (1806-1856), wyróżnił słowiańską forma mentis, czyli słowiański typ myślenia. ${ }^{17}$ Tego rodzaju poglądy Bernard Schulte nazwał „nową gnozą rosyjską” lub „chrześcijańskim humanizmem”, „chrześcijańskim człowieczeństwem". ${ }^{18}$ Istnieje wiele różnych poglądów dotyczących ludzkiego wyposażenia personalnego. Co więcej, panuje chaos związany z fundamentalnymi terminami personalnymi, takimi jak: „osoba”, „substancja”, „substancja duchowa”, „dusza”. Trudno oceniać koncepcje antropologiczne czy też tworzyć samemu nową koncepcję w sytuacji chaosu terminologicznego. Potrzebne jest uporządkowanie, a także uzupełnienie - przywrócenie terminów odsuniętych do lamusa czy nawet tworzenie nowych. Zajmuje się tym m. in. lubelski teolog Czesław Bartnik. Zauważył on, że „sytuację językowo-ontologiczną wspiera strona medialna: «mnie», «tobie», «sobie», «se», występująca niekiedy między stroną czynną czasowników (activum) i stroną bierną (passivum). Szkoda, że dziś strona medialna (medium) zanika niemal całkowicie. Sprawia to chyba zanik świadomości personalistycznej”. ${ }^{19} \mathrm{~W}$ tej sytuacji, refleksja nad sposobem powiązania aspektów personalnych z duszą i ciałem nie jest spokojnym rozwijaniem antropologii chrześcijańskiej, lecz nieustanną walką i troską o prawidłowe i pełne odczytywanie treści objawienia.

Potrzebna jest nie tylko lepsza teoria. Konieczna jest zmiana nawyków językowych w praktyce życia codziennego. Powszechnie mówi się: „mam ciało”, „mam duszę”, „moje ciało”, „moja dusza”, podczas gdy trzeba mówić: ,jestem ciałem”, ,jestem duszą”, „moja dusza,

17 Zob. P. A m b r o z, Bernard Schulte nel contesto della teologia cattolica e ortodossa, Acta Palackianae Universitatis Olomucensis, Theologica Olomucensia t. 1/1999, s. 35 .

18 Zob. tamie, s. 36.

19 Cz. S. B a r t n i k, Personalizm, s. 64. 
czyli ja” itp. Na krzyżach misyjnych umieszczany jest napis: „Ratuj duszę swoją”. Niektórzy uważają, że trzeba mówić też „ratuj ciało swoje". Niepoprawność nie polega jednak na zapominaniu o sferze cielesnej, bo o ciało ludzie się troszczą, natomiast o duszę nie za bardzo, i z tego względu trzeba przypominać właśnie o duszy. Niepoprawne jest sugerowanie, że człowiek jest jakimś trzecim bytem, natomiast duszę i ciało „się ma”. Tymczasem powinno być napisane: „Człowieku, który jesteś duszą i ciałem, ratuj siebie”, ewentualnie: „Duszo, ratuj siebie”. Tego rodzaju sformułowanie wywołałoby konsternację, ponieważ błędny sposób myślenia jest silnie zakorzeniony w świadomości ogółu. Niestety, naprawdę zanika świadomość personalistyczna, zanika świadomość tego, kim jestem. Język jest tego odzwierciedleniem.

Personalizm stwierdza, że poznanie rzeczywistości jest proporcjonalne do zrozumienia osoby. Personalizm zwraca uwagę na to, że „dla człowieka rzeczywistość zaczyna się wraz z osobą, przebiega przez sam środek osoby i spoczywa, osiągając swój cel, w osobie". ${ }^{20}$ Z kolei coraz lepsze rozumienie rzeczywistości otaczającej człowieka pozwala coraz lepiej zrozumieć jego personalność

\section{Struktura substancji czlowieka $\mathbf{w}$ świetle relacji z Bogiem i ze światem}

Ludzka substancja duchowa ma w sobie „cielesność”, coś, co otwiera ją na materię i pozwala z jej części utworzyć ciało - swoje ciało. Wszystko to, jak i całe duchowe wyposażenie, dane zostało w akcie stwórczym. Wzorcem jest Bóg, w którym jest akt stwórczy w sensie odwiecznego działania wpisanego w życie Trójcy Osób. Nie można zrozumieć, jak to się stało, że Bóg - w którym nie ma czasu w pewnym „momencie” sprawił pojawienie się świata. Odwieczny zamysł Boży zaktualizował się. Z jednej strony jest bezczasowa przyczyna (plan, wzorzec), z drugiej jest nasz świat. Sam ,punkt początkowy" jest niemożliwy do uchwycenia. Również człowiek jest bytem

20 Te n ż e, Dogmatyka katolicka, s. 399. 
stworzonym. Struktura substancji człowieka jest ściśle powiązana ze strukturą życia Boga i strukturą aktu stwórczego, zmienia się, wraz z dążeniem do pełni zjednoczenia z Bogiem. Oznacza to, że wewnętrzna struktura duszy i ciała wyznaczona jest nie tylko przez ich wzajemne łączenie się, ale też przez relację z Bogiem i całym światem. Ponadto wszystkie relacje, jak też wewnętrzne elementy duszy i ciała zmieniają się. W integralnym opisie struktury wszystkie te czynniki powinny być uwzględnione.

Nie istnieje bezpośrednia więź substancji człowieka z substancją Boga. Nawet się ze sobą nie stykają. Czy w tej sytuacji można mówić o wszczepieniu, przebywaniu, jedności? Można, ale bezpośrednio nie w warstwie refleksji nad substancją, lecz w refleksji nad innymi aspektami, którymi są relacje, wnętrze, wygląd, działanie. Bóg wraz ze stworzeniami tworzy uniwersalną tkaninę bytu, utkaną z istnienia, życia, myśli, uczuć i woli, zachowując substancjalną odrębność. Najmocniejsza jest więź Boga ze stworzonymi osobami, następnie z bytami żyjącymi, a wreszcie z całą materią. Odpowiednio też w jakiś sposób złączony jest cały świat, mocniej byty ożywione a najmocniej byty personalne z zachowaniem swej autonomii substancjalnej.

Wszystko to jest tłem do refleksji nad strukturą substancji człowieka zmierzającej do zbudowania integralnego modelu antropologicznego. Nie uczynił tego św. Augustyn, ponieważ nie operował odpowiednim pojęciem osoby, nie wypracował integralnej definicji osoby. Jego trynitologia „,psychologiczna” tworzona za pomocą analogii do psychiki ludzkiej była oderwana od innych konstytutywnych aspektów każdego bytu, a szczególnie personalnego. Najważniejsze w systemie Augustyna jest spostrzeżenie, że substancja osoby ludzkiej uformowana jest na obraz Boży, odzwierciedla w sobie życie wewnętrzne Boga Stworzyciela. Z tego wynika, że forma ciała, czyli dusza, ma kształt trynitarny, a tym samym również w ciele ludzkim jest jakaś trynitarność. Również inni myśliciele chrześcijańscy ograniczali swoje refleksje albo do Trójcy transcendentnej (tematem są tylko relacje wewnątrz substancji Boga), albo do Trójcy ekonomicznej, działającej zbawczo w świecie (też uwzględniane tylko niektóre aspekty personalne). Brak integralności w trynitologii, a także zbyt 
schematyczna chrystologia, to przyczyna niedorozwoju antropologii chrześcijańskiej. Refleksje nad strukturą substancji człowieka wymagają rozwiniętego zaplecza ogólno-teologicznego. W jaki sposób Syn Boży jest człowiekiem, a jednocześnie, wraz z Ojcem i Duchem Świętym jest jednym Bogiem?21 Wyjaśnienie sposobu wszczepienia się natury ludzkiej Chrystusa w Boga Jedynego jest kluczem i fundamentem do wyjaśnienia sposobu przebywania w Bogu wszystkich odrębnych bytów stworzonych oraz ich całości.

Więź substancjalna tworzona jest pośrednio przez działanie personalne we wszystkich możliwych aspektach. Bardzo ważnym elementem natury ludzkiej jest myślenie. Oznacza to, że już sama refleksja, czyli poznawanie treści i budowanie systemu teologicznego, jest tworzeniem relacji z Bogiem, wchodzeniem do wnętrza życia Boga. Kierowanie myśli ku Bogu powinno być wplecione w integralne dążenie człowieka do Boga. Objawienie jest ruchem niewidzialnego ku widzialnemu (proodos), teologia kieruje świat widzialny ku niewidzialnemu Bogu (epistrophe). W ten sposób poznanie intelektualne jest wplecione w proces wchodzenia osoby ludzkiej do wnętrza życia Bożego. ${ }^{22}$ Odczytywanie i refleksja nad słowem Bożym to wchodzenie człowieka w nurt działania Boga, który przychodzi, aby zjednoczyć się z ludźmi i włączyć ich w nurt swego życia wewnątrz-boskiego. ${ }^{23}$

Najwyższym skutkiem Bożego działania w człowieku jest łaska, czyli wywyższenie relacji człowieka z Bogiem w doczesności. Dzięki temu, człowiek zostaje włączony w działanie Boże wstępujące, którego celem jest wieczne życie człowieka we wnętrzu Boga. Już w doczesności, człowiek przemieniany łaską przebywa w odpowiednio przemienionym czasie (kairos). Przemieniane są również czas, przestrzeń i materia, stając się coraz wspanialszym środowiskiem życia ludzi. W procesie wstępowania są przemieniane nie tylko

21 Tamże, s. 208.

22 Por. S. Z a m b o n i, Luce dell'essere, Dio della tenebra, Ermeneutica della luce nel "Corpus areopagiticum”, Ricerche Teologiche 10/1999, s. 121.

23 Por. tamie, s. 122. 
przez Boga, lecz również przez ludzi. ${ }^{24}$ Dzięki temu przemienia się struktura substancjalna, jest coraz bardziej gęsta personalnie, coraz bardziej podobna do substancji Boga. ${ }^{25}$ Substancja ludzka tworzy historię, a przemiany historyczne wpływają na przemianę ludzkiej substancji. Celem ostatecznym jest wejście człowieka integralnego, w swej substancji i ze swoją historią, do wnętrza życia Boga. ${ }^{26}$

W świecie materialnym istnieje tzw. spin, czyli piąty wymiar, obok trzech przestrzennych oraz czasu. Spin to skondensowana czasoprzestrzeń, to miejsce spotkania się świata z Bogiem, w którym dokonuje się koordynacja substancji duchowej niestworzonej z materią, oraz z innymi substancjami duchowymi: ludzkimi oraz anielskimi. Dokonuje się to w każdym punkcie substancji ludzkiej i w jej całości ${ }^{27}$ Odpowiednio też obraz Trójcy Świętej jest w każdym punkcie substancji człowieka i w jej całości. Oznacza to, że w substancji ludzkiej dokonuje się - analogicznie jak w Bogu - trynitarne przechodzenie (circumincessio) i przebywanie (circuminsessio). Wieczne i absolutne przelewania się wzajemne Osób Bożych odwzorowane jest w życiu osób ludzkich, wewnątrz i na zewnątrz, w relacji z innymi bytami personalnymi i niepersonalnymi. Życie trynitarne odwzorowane w osobach stworzonych zmienia się, narasta, aż do osiągnięcia pełni, w wieczności, gdzie będzie wieczny „czas”, wieczny „ruch”, wieczne życie, zanurzone w życiu Absolutu. W miarę upływu czasu (chronos) narasta w człowieku ,zakrzywienie” energii personalnej ku Bogu, jej istnieniowe, personalne ,zagęszczenie”. Wszystkie elementy personalne stają się coraz mocniejsze a jednocześnie są coraz bardziej zintegrowane w osobowej całości. Pełnia osoby ludzkiej zanurzonej w Bogu nie oznacza zaniku substancji, lecz jej bytowanie w maksymalnej mierze odpowiedniej dla danego byty stworzonego.

24 Por. J. L. R u i z d e 1 a P e ñ a, La otra dimensión, Santander 1986, s. 19.

25 Por. X. Z u b i r i, Naturaleza, Historia, Dios, Madrid 1963, s. 328.

26 M. F e r n a n d e z d e 1 R i e s g o, Existencias teológicas de una filozofiía de la historia (La Resurrección como teodicea radical), Ciencia Tomista 388/1992, s. 322 .

27 Por. C. S o r c, La historia en su dimensión pericorética, Actas del X Simposio de Teología Histórica 3-5 marzo 1999, Valencia 2000, s. 519. 
Pełnia osobista jest harmonijnie powiązana z pełnią społeczną, ${ }^{28} \mathrm{która}$ dokonuje się w Chrystusie, przez unię hipostatyczną, w mocy Ducha Świętego. ${ }^{29}$

\section{Wymiar społeczny relacyjności substancji ludzkiej. Struktura społeczna substancji czlowieka}

Ważnym aspektem osoby jest relacyjność. Substancja personalna jest relacyjna ze swej istoty. Relacja personalna to nie coś pośrodku, między osobami, lecz coś, co identyfikuje się z substancją. Jest to jedna i ta sam rzeczywistość, która stanowi budulec ontyczny i sprawia jednoczenie się z innymi. Im bardziej osoby są zjednoczone ze sobą nawzajem, tym mocniejsza jest personalność tworzonego przez nie bytu społecznego. Najmocniejsza jest więź społeczna Kościoła - Ciała Chrystusa. Nie ma w Piśmie Świętym nazwy „Kościół Osoba". Jest tylko mowa o jednym organizmie w sensie soma. Kościół nie jest Osobą Chrystusa, lecz tylko Jego „Ciałem”. Oznacza to, że ma wiele cech wspólnych z Osobą Chrystusa, ale nie wszystkie. W każdym razie, wśród wszystkich społeczności najwyższy poziom personalności ma Kościół. Wynika to z maksymalnego uczestniczenia w życiu Osób Bożych. Zagadnienie to wymaga pogłębienia $\mathrm{w}$ aspekcie antropologicznym, chrystologicznym i trynitarnym. ${ }^{30}$ Najważniejsze jest, że Duch Święty przebywa wśród ludzi, gromadzi ich wokół Jezusa Chrystusa i jednoczy z Nim. ${ }^{31}$ Działanie Osób Bożych w życiu wewnętrznym Boga sprawia, że są jedną wspólną substancją: niestworzoną, absolutną. Byty stworzone są tylko w pewien sposób zanurzone w życiu Osób Bożych, są przez Nie wpychane/ wsysane w substancję Bożą. Wykluczone jest przemieszanie się sub-

28 Por. P. C o r m i e r, Problem osoby, w: Tajemnica Trójcy Świętej, Kolekcja Communio 13, Poznań-Warszawa 2000, s. 344.

29 Por. tamże, s. 345.

30 Por. P. L i s z k a, Duch Święty twórca Kościoła. Ujęcie personalistyczne integralne, Perspectiva 2/2011, s. 174

31 Por. tamże, s. 175. 
stancji, utożsamienie bytów stworzonych ze Stworzycielem, z Bytem Absolutnym. Ważne jest to, że relacja zbawcza oznacza wszczepienie/uczestniczenie stworzeń w życie Osób Bożych. Stworzenia są zanurzone w Boską rzekę, w Boski nurt, który na poziomie Osób Bożych dzieje się w sposób odwieczny, absolutny, któremu odpowiada słowo „Jest”. W trynitologii, jednoczenie/jedność Osób Bożych określa termin proballein. Osoby Boże emanują siebie w pozostałe dwie, odwiecznie, w jednej i tej samej substancji. Nie ma emanacji Boga w stworzenia i stworzeń w Boga. Jednoczenie dokonuje się na miarę bytową stworzeń. Sprawcą jednoczenia jest Bóg Stworzyciel. W najwyższy sposób z substancją Boga jednoczeni są ludzie, w Mistycznym Ciele, w mocy Ducha Świętego. ${ }^{32}$

W tym kontekście można mówić o „osobie społecznej”, ale tylko w sensie aspektowym. Społeczność osób stworzonych nie jest osobą, nie ma swojej substancji, jest to zbiór substancji odrębnych. Jest natomiast wspólna subsystencja (subsistentia communis), czyli wszczepienie indywidualnych energii personalnych we wspólną energię społeczną. Zbiorowe ego nie jest indywidualne, jest zbiorem poszczególnych jaźni, które razem tworzą jedno „my” (ego collectivum) w tym sensie, że może być wspólna myśl, wola i uczucia. W tym kontekście Czesław Bartnik podaje określenie: „Osoba społeczna jest to konkretne, określone przez bazę naturalną, współkonstytuowanie się, współrealizowanie i współżycie danej zbiorowości osób, jednych dzięki drugim nawzajem". ${ }^{33}$

Osoba w pełnym tego słowa znaczeniu, indywidualna, utkana jest z sieci relacji: wewnętrznych (dusza z ciałem) i zewnętrznych (z innymi bytami). Substancja duchowa i materialną łączą się, ale nie tworzą jakiejś trzeciej substancji, lecz misteryjną nad-syntezę, z którą identyfikuje się indywidualna jaźń. W osobie ludzkiej nie ma zlewania się substancji ani też ich dualnego wyposażenia wewnętrznego. Jest natomiast wspólna relacyjność, oblicze i działanie. W zasadzie w każdej warstwie bytowej jest dualność w jedności.

32 Por. tamże, s. 181.

33 Cz. S. B a r t n i k, Personalizm uniwersalistyczny, RTK 2/2002, s. 80. 
Inne są: relacyjność, oblicze i działanie ciała, a inne: relacyjność, oblicze i działanie duszy. Wszystkie te warstwy personalne są dualne, ale zjednoczone. Im mocniejsze jest ich zjednoczenie, im większa integralność, tym większa moc personalna. ${ }^{34}$

Wszystko to, co zostało powiedziane o strukturze złożenia duszy z ciałem, analogicznie odnosi się do jednoczenia się osób ludzkich w jeden organizm społeczny.

Subsystowanie ciała i duszy w osobie nie oznacza pojawienie się jakiejś nowej substancji, w którą wszczepione są substancja duchowa i materialna. Osoba nie jest czymś trzecim, nie jest jakimś nowym podłożem dla duszy i ciała, zewnętrznym wobec nich. Osoba ludzka jest złożona $\mathrm{z}$ dwóch substancji różnego rodzaju, bez rozdzielenia i bez zmieszania. Może istnieć dusza bez ciała, ale gdy jest z ciałem, to tworzy z nim autentyczną jedność. Byt duchowo-somatyczny to nie jakaś trzecia substancja, lecz sposób istnienia ciała i duszy, sposób bycia ich w relacji. $\mathrm{Z}$ istoty swojej relacyjna jest tylko substancja duchowa. Ciało otrzymuje relacyjność personalną od duszy. Ciało zjednoczone z duszą jest zdolne do tworzenia personalnych relacji wobec innych bytów. ${ }^{35}$ Człowiek mówi o sobie ,ja” w swej całości duchowo-cielesnej. Wszelkie czyny dotyczą całej osoby, aczkolwiek różny jest stopień zaangażowania duszy i ciała. ${ }^{36}$ Zarówno dusza jak i ciało uczestniczą w rozwoju struktury personalnej własnej, całej osoby i społeczności osób. ${ }^{37}$ Osoby ludzkie i sieć relacji społecznych tworzą spójną całość. Z tego względu pojawia się konieczność współpracy i wzajemnej odpowiedzialności jednych za drugich i za cała społeczność. W ten sposób dokonuje się realizacja Bożego zamysłu, zapisanego we wnętrzu życia Osób Bożych.

34 Por. tamże, s. 81.

35 Por. t e nż e, Ku definicji osoby, s. 9.

36 Zob. C.-J. P i n t o d e O li v e i r a, Éthique chrétienne et dignité de l'homme, Éd. Universitaires, Fribourg 1992, s. 149; L. S e n t i s, Penser la personne, Novuelle revue théologique 116/1994, s. 679.

37 Zob. J. M o in g t, Théoloqie trinitaire de Tertullien, Aubier Montaigne, Paris 1966; zwł. t. 2, s. 551-674. 
Jednoczenie się substancji duchowych dokonuje się też przez tworzenie i umacnianie relacji na płaszczyźnie materialnej, także przez tworzenie historii. Oznacza to, że refleksja dotycząca duszy ludzkiej staje się też refleksją dotyczącą społeczeństwa i historii. ${ }^{38}$ Centralną rolę odgrywa w tym Jezus Chrystus. Nie można zrozumieć człowieka bez Chrystusa, a także nie można zrozumieć historii ludzkości bez Trójcy Świętej. Wszelkie próby ateistyczne, czy nawet teistyczne, ale antytrynitarne są skazane na niepowodzenie. ${ }^{39}$ Historia ludzkości to dramat rozgrywający się na dwóch scenach: boskiej i ludzkiej (Hans Urs von Balthasar). Kluczowym problemem jest sposób łączenia się dwóch scen: niestworzonej i stworzonej, a ponadto sposób łączenia się płaszczyzny duchowej z materialną. Wszystkie te zagadnienia skondensowane są w tajemnicy Jezusa Chrystusa. Tego rodzaju ujęcie integralne pozwala zauważyć, że w dziejach świata są „,miejsca osobliwe": stworzenie, wcielenie Syna Bożego wraz z Paschą i koniec świata. Są to miejsca zagęszczenia przenikania się niestworzonego i stworzonego, duchowego i materialnego, a wszystko w schemacie działania trynitarnego. ${ }^{40} \mathrm{Na}$ końcu świata Bóg będzie wszystkim we wszystkich, przez rekapitulację wszystkiego w Chrystusie, mocą Ducha Świętego. ${ }^{41}$

Wszystkie te zagadnienia czekają na gruntowne opracowanie. Do tej pory szczytem myśli teologicznej jest Bartnikowe mówienie o „duszy społecznej” (anima communio), tajemniczym zespoleniu dusz jednostek w jedność wyższego rzędu, o wymiarze duchowym społeczności. Lubelski teolog informuje, że tym zagadnieniem zajmuje się „pneumatologia społeczna” (pneumatologia socialis). Efektem działania Ducha Świętego jest „podmiotowość społeczna” (cor unum), ,jaźń społeczna” (ego societatis, ego commune) czy

38 Por. B. J. H i 1 b e r a th, Der dreieinige Gott und die Gemeinschaft der Menschen, Mainz 1990. Autor wymienia teologów podejmujących ten temat: L. Boff, K. Hemmerle, J. Moltmann, B. Forte.

39 Zob. A. D u p 1 e i x, Dio-Trinita. Una chiave di lettura per un nuovo dialogo con l'uomo contemporaneo, Nova humanista 19 (1997) nr 109, s. 145-163.

40 Por. C. S o r c, La historia en su dimensión pericorética, s. 519.

41 Por. tamże, s. 520. 
w ogólności „osoba społeczna” ( persona collectiva, communio)..$^{42}$ Tak więc teologowie mają do dyspozycji zestaw terminów, rozwiniętą trynitologię i antropologię oraz opracowania H. Balthasara. Trzeba jeszcze zespolonego wysiłku zmierzającego do wielkiego model całościowego, który wykracza poza metafizykę Arystotelesa, która zatrzymuje się na spostrzeżeniu, że osoby jednostkowe stanowią „materię pierwszą” czy „substancję pierwszą” dla „substancji społecznej”, które są niewystarczające do opisywania treści zawartych w objawieniu Chrystusowym, spisanym w Nowym Testamencie.

Pojawia się pokusa ograniczenia refleksji do płaszczyzny materialnej albo do wymieszania obu płaszczyzn. Tego rodzaju próby były podejmowane przez idealizm niemiecki oraz w nurcie myśli rosyjskiej, będącej wyraźnie pod jego wpływem. Skończyło się to materialistyczną wizją człowieka kosmicznego oraz bolszewicką wizją ,duchowego Proletariusza”. Idealistyczny, abstrakcyjny panteizm filozofów niemieckich z XIX w. przemienił się tam w materialistyczną wizję żywego kosmosu. ${ }^{43}$ Nauczanie społeczne Kościoła ogranicza się do opisywania działania historycznego. Zagadnienia ontologiczne pozostawiono teologii dogmatycznej. ${ }^{44}$

Teolog może korzystać z różnych źródeł, które inspirują i tworzą jakiś ogólny szkic, rozbudowaną strukturę myśli z konsekwentnym zachowaniem chrześcijańskiej aksjomatyki, zawartej w Nowym Testamencie i sformułowanej w postaci orzeczeń dogmatycznych. Dziś teologia dogmatyczna nie ogranicza się tylko do metafizycznych schematów, lecz buduje model całościowy. Model integralny ukazuje wyraźnie, że „indywidualny byt ludzki nie jest zlepkiem różnych

42 Zob. Cz. S. B a r t n i k, Dogmatyka katolicka, s. 412.

43 Zob. A. P o m o r s k i, Duchowy proletariusz. Przyczynek do dziejów lamarkizmu społecznego i rosyjskiego komunizmu XIX-XX wieku (na marginesie antyutopii Andrieja Płatonowa), Wydawnictwo Naukowe i Literackie, Warszawa 1996.

44 Zob. J. M. M a g a z, El miedo a la libertad en "El ensayo" de Donoso Cortés, Studium 1/1999, s. 95-131; zob. P. L e t u r i a, Previsión y refutación del ateismo komunista en los últimos escritos de Juan Donoso Cortés: 1848-1853, Gregorianum 18/1937, s. 481-517. 
elementów, składników (materii, ciała, energii, idei, dusz)". ${ }^{45}$ Zarówno jednostkowy człowiek, jak i społeczność, to organiczna jedność, w której poszczególne elementy są połączone siecią wielorakich relacji. Orzeczenia dogmatyczne mówią o substancji niestworzonej oraz o dwóch substancjach stworzonych: materialnej i duchowej, a także o dwóch rodzajach energii duchowych: niestworzonej i stworzonej. Nie wystarczy powiedzieć, że człowiek jest integralną i nierozwijalną całością. Trzeba zbadać, w jaki sposób te elementy się łączą, w jaki sposób tworzą integralną całość. Ksiądz Bartnik nie przekreśla mnogości, lecz zauważa, że w społecznej całości ,,jedność panuje nad mnogością". Zwieńczeniem tej myśli jest stwierdzenie, że mnogość „zmierza ku jedności”. ${ }^{46}$

Wzorcem personalności społecznej jest Trójca Święta. W tym kontekście trzeba $\mathrm{z}$ wielką ostrożnością podchodzić do terminu „osoba społeczna”, który jest stosowany w odniesieniu do społeczności ludzkich. Przeniesiony na sferę Boskości, schemat ten traktuje trzy Osoby jako jedną Osobę - społeczną. Tymczasem Bóg nie jest Osobą, lecz trzema Osobami. Osoby różnią się specyficznym wyposażeniem wewnętrznym, specyficzną relacyjnością. Łączy je nie tylko wspólna substancja, ale to, że każda z nich ma wszystkie elementy istotne w integralnej definicji osoby $i$ to na miarę absolutu. Wzorcem dla bytów stworzonych jest nie tylko trynitarny schemat, lecz dynamizm życia, który jest w świecie stworzeń realizowany w przestrzeni i czasie, na miarę ograniczoną, skończoną. Relacja ludzi z Bogiem wprowadza element absolutny w świat stworzony, w materię, przestrzeń i czas. Wszystko zmierza ku pełni, która będzie osiągnięta $\mathrm{w}$ wydarzeniu paruzji.

$$
* * *
$$

Elementy personalne w człowieku są ze sobą powiązane i razem tworzą spójną całość. Fundamentalna struktura w osobie ludzkiej to

45 Cz. S. B a r t n i k, Personalizm, Lublin $2008^{3}$, s. 75.

46 Tamże. 
struktura tworzona przez elementy wyposażenia duchowego. $Z$ tego, że dusza ludzka jest formą substancjalną ciała ludzkiego, wynika, że również w ciele jest swoista struktura duchowa. Te dwie rzeczywistości tworzą wspólne strukturę personalną człowieka. Zbiór struktur personalnych indywidualnych tworzy razem strukturę personalną społeczną. Każda z wymienionych struktur jest odwzorowaniem struktury znajdującej się w substancji Boga Trójjedynego, z nią jest w taki czy inny sposób powiązana i zmierza do eschatologicznej pełni.

Piotr LISZKA CMF

Słowa kluczowe: struktura, ciało, dusza, osoba ludzka, społeczność, relacja, autonomia, jedność

Keywords: structure, body, soul, human being, community, relation, autonomy, unity

\section{The substantial structure of a human being}

Summary

The statement that a human being is a soul and a body is not sufficient. The way their union comes about in the mutual creation of one human being is what matters. Moreover, the spiritual substance of a human being has a different structure than the material substance, yet there is some similarity, indeed something in common. The most difficult issue refers to the existence of the spiritual element in the body, which unites it with the soul and creates the human body out of it. The combination of body and soul, as well as the human community, has its structure. Individual human beings and communities are engrafted in the life of the Triune God. The substantial structure of a human being constitutes the foundation of the social structure and coherent wholeness with the structure of life of the Divine Persons. 